\title{
Review \\ Production of Vitamin K by Wild-Type and Engineered Microorganisms
}

\author{
Min-Ji Kang ${ }^{\dagger}$, Kwang-Rim Baek ${ }^{\dagger}$, Ye-Rim Lee ${ }^{\dagger}$, Geun-Hyung Kim and Seung-Oh Seo *(D) \\ Department of Food Science and Nutrition, The Catholic University of Korea, Bucheon 14662, Korea; \\ escape97@catholic.ac.kr (M.J.K.); rimmy@catholic.ac.kr (K.-R.B.); yerim61@catholic.ac.kr (Y.-R.L.); \\ ruby7216@catholic.ac.kr (G.-H.K.) \\ * Correspondence: drsos@catholic.ac.kr; Tel.: +82-2-2164-4316 \\ + These authors contributed equally to this work.
}

check for updates

Citation: Kang, M.-J.; Baek, K.-R.; Lee, Y.-R.; Kim, G.-H.; Seo, S.-O.

Production of Vitamin K by

Wild-Type and Engineered

Microorganisms. Microorganisms 2022, 10, 554. https://doi.org/ 10.3390/microorganisms10030554

Academic Editor: Philippe Soucaille

Received: 31 January 2022

Accepted: 1 March 2022

Published: 3 March 2022

Publisher's Note: MDPI stays neutral with regard to jurisdictional claims in published maps and institutional affiliations.

Copyright: () 2022 by the authors Licensee MDPI, Basel, Switzerland. This article is an open access article distributed under the terms and conditions of the Creative Commons Attribution (CC BY) license (https:// creativecommons.org/licenses/by/ $4.0 /)$.

\begin{abstract}
Vitamin $\mathrm{K}$ is a fat-soluble vitamin that mainly exists as phylloquinone or menaquinone in nature. Vitamin K plays an important role in blood clotting and bone health in humans. For use as a nutraceutical, vitamin $\mathrm{K}$ is produced by natural extraction, chemical synthesis, and microbial fermentation. Natural extraction and chemical synthesis methods for vitamin K production have limitations, such as low yield of products and environmental concerns. Microbial fermentation is a more sustainable process for industrial production of natural vitamin $\mathrm{K}$ than two other methods. Recent advanced genetic technology facilitates industrial production of vitamin $\mathrm{K}$ by increasing the yield and productivity of microbial host strains. This review covers (i) general information about vitamin $\mathrm{K}$ and microbial host, (ii) current titers of vitamin K produced by wild-type microorganisms, and (iii) vitamin K production by engineered microorganisms, including the details of strain engineering strategies. Finally, current limitations and future directions for microbial production of vitamin $\mathrm{K}$ are also discussed.
\end{abstract}

Keywords: vitamin K; production; microorganisms; fermentation; metabolic engineering

\section{Introduction}

Vitamin K refers to fat-soluble vitamins which play a role in human health, including blood coagulation and bone health [1]. Vitamin K exists as phylloquinone or menaquinone in nature [2]. Phylloquinone is called vitamin $\mathrm{K} 1$ and is found in the green leaves of vegetables [3]. Menaquinone is called vitamin K2 and is mainly produced by bacteria [4]. Various fermented foods made by bacteria such as Natto (Japanese fermented soybean), Cheonggukjang (Korean fermented soybean), and various cheeses are the main sources of menaquinone uptake [5,6]. Menaquinone is also found in foods of animal origin, such as eggs and meat, in small amounts [6]. Vitamin K has the 2-methyl-1,4-naphthoquinone ring as a core structure, and the side-chain at the C3-position of the naphthoquinone ring structure (Figure 1A) [5]. Phylloquinone has a partially unsaturated side chain consisting of one isopentenyl followed by three isopentyl units, while menaquinones have a fully unsaturated side chain composed of 2 to 13 isopentenyl units [7]. Menaquinone has various subtypes that have a different number (n) of isoprenoid units called menaquinone-n (MKn) [8]. For example, MK-4 contains four isoprenoid units at the side chain connected to a 2-methyl-1,4-naphthoquinone ring. The structural difference of vitamin K affects biological functions [9]. The isoprene side chain of vitamin $\mathrm{K}$ affects half-life and intestinal absorption of vitamin K [10]. Due to the structural difference, biological activity among various vitamin $\mathrm{K}$ forms varies despite similar modes of action [11]. 

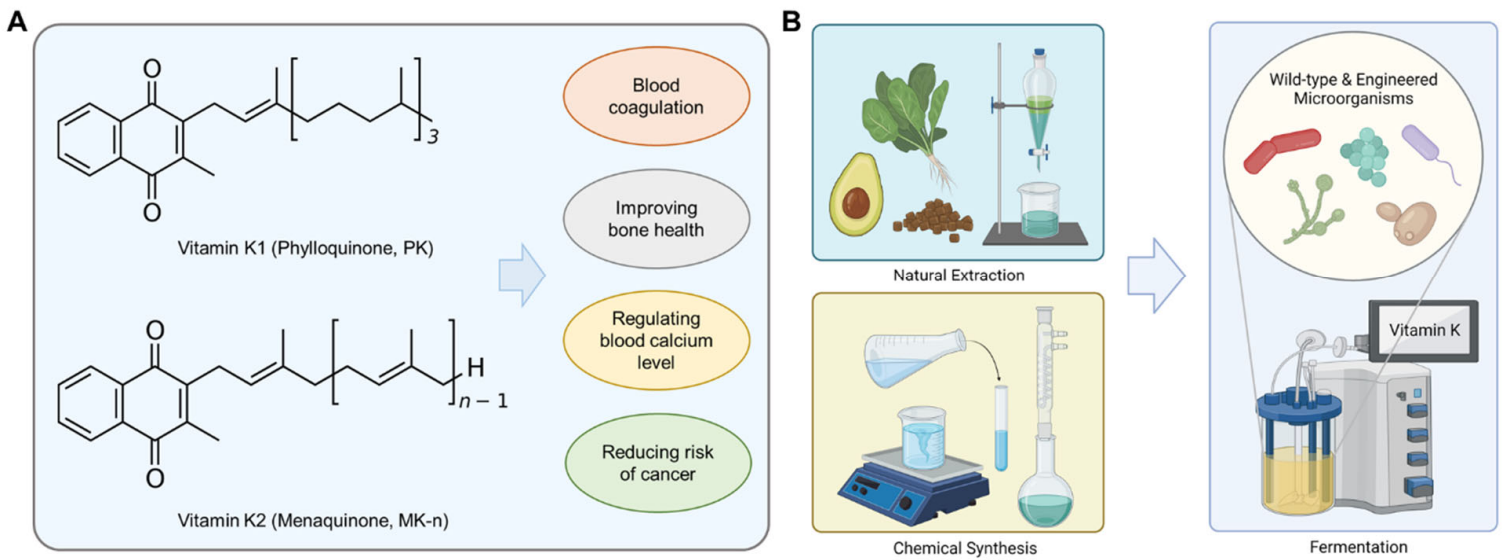

Figure 1. Vitamin K production using microorganisms. (A) Chemical structures of vitamin $\mathrm{K}$ and its biological functions, and (B) Methods of vitamin K production including natural extraction, chemical synthesis, and fermentation.

In mammals, vitamin $\mathrm{K}$ is an essential micronutrient exhibiting several biological functions such as blood coagulation, improving bone health, regulating blood calcium level, preventing cardiovascular disease (CVD), and reducing the risk of cancer (Figure 1B) [12]. Vitamin $\mathrm{K}$ is an essential cofactor for the production of blood clotting factors [13-15]. Due to this effect, the name of vitamin K came from the German word "Koagulations" [16]. Many clinical studies also suggest that vitamin K plays an important role in bone health, such as preventing osteoporosis $[17,18]$. Vitamin $\mathrm{K}$ has been considered as a powerful micronutrient in aging and age-related diseases [19]. Notably, menaquinone is considered and used as an emerging anti-osteoporosis drug [20,21]. Moreover, vitamin K might be related to reducing risk of CVD by preventing vascular calcification [22-25]. Vitamin $\mathrm{K}$ is also related to brain health since it is a cofactor for the activation of two proteins, Gas6 and protein S, that are related to the cognitive process in the brain [26]. Moreover, vitamin $\mathrm{K}$ affects the metabolism of sphingolipids which are associated with cellular events in the brain [26]. A reduced form of vitamin $\mathrm{K}\left(\mathrm{KH}_{2}\right)$ directly protects phospholipid membranes from peroxidation by reactive oxygen species (ROS), suggesting its antioxidant activity [27]. Particularly, phylloquinone and MK-4 inhibit activation and accumulation of 12-lipoxygenase (12-LOX) enzyme in cultured neurons and oligodendrocytes, thereby preventing cell death caused by oxidative stress [28,29].

As a nutraceutical and dietary supplement, vitamin $\mathrm{K}$ is currently produced by natural extraction, chemical synthesis, and microbial fermentation (Figure 1B) [30]. Several manufacturers of vitamin K mainly use a chemical synthesis method [30-32]. Chemical synthesis requires multiple reaction steps, thereby reducing the yield and selectivity of vitamin $\mathrm{K}$ by forming unwanted byproducts and isomers [30]. Similar to chemical synthesis, extraction of vitamin $\mathrm{K}$ from natural products also has a low yield problem by complex pretreatment processes [33]. Recently, microbial fermentation has been used for industrial production of vitamin K [34]. Microbial production is a more sustainable option than chemical synthesis since it avoids the use of heavy metals, organic solvents, strong acids, and bases [35]. Microbial fermentation can also produce the final products more economically from inexpensive sources of energy, carbon, electrons, and trace nutrients [36]. Even though the chemical synthesized vitamin $\mathrm{K}$ can be made for high purity of all-trans vitamin $\mathrm{K} 2$ which has biological activity $[37,38]$, it still has product safety concerns for use as a GRAS food supplement [39].

Several wild-type microorganisms isolated from various environments have been used for industrial production of vitamins [39,40]. Native vitamin producers have several limitations, such as low yield and productivity with genetic instability [41]. To produce vitamins with high yield and stability through fermentation, metabolic engineering of microorganisms can be applied [42]. Furthermore, bioprocess engineering approaches 
such as optimization of fermentation conditions and medium composition can also be applied to improve the yield of products [43]. Various strain engineering methods were applied to vitamin productions by microbial cell factories, such as Bacillus and lactic acid bacteria (LAB) [44,45]. Recently, advanced genome editing tools such as the CRISPR/Cas9 system have been used for vitamin production in bacteria such as E. coli [46]. In this review, we provide recent progress on vitamin $\mathrm{K}$ production by wild-type and engineered microorganisms with details of strain engineering and fermentation strategies. We also discuss current limitations and future directions for microbial production of vitamin $\mathrm{K}$.

\section{Production of Vitamin K by Wild-Type Microorganisms}

\subsection{Bacillus}

Bacillus subtilis var. natto is a well-known vitamin K producer isolated from Natto [47]. B. subtilis is a GRAS (generally recognized as safe) host microorganism widely used for the production of food ingredients [48]. Owing to this property, many researchers have attempted to produce vitamin $\mathrm{K}$ such as menaquinone using B. subtilis natto (Table 1 ). Berenjian et al. (2011) produced MK-7 using B. subtilis natto strain by optimizing the medium composition and fermentation conditions [49]. The authors found optimal fermentation medium for MK-7 production, consisting of 5\% (w/v) yeast extract, $18.9 \%(w / v)$ soy peptone, $5 \%(w / v)$ glycerol, and $0.06 \% \mathrm{~K}_{2} \mathrm{HPO}_{4}$. After the fermentation of $B$. subtilis natto at $40{ }^{\circ} \mathrm{C}$ for $144 \mathrm{~h}$, the maximum titer of MK-7 reached $62.32 \mathrm{mg} / \mathrm{L}$ [49]. As a follow-up study, Berenjian et al. (2011) attempted to produce MK-7 in fed-batch fermentation using glycerol by B. subtilis natto strain. The authors achieved $68.6 \mathrm{mg} / \mathrm{L}$ of MK-7 in $144 \mathrm{~h}$ of fermentation by intermittent addition of $2 \%(w / v)$ glycerol during fermentation [50]. Berenjian et al. (2012) performed scale-up experiments for MK-7 production using the same strain of $B$. subtilis natto in a $3 \mathrm{~L}$ bioreactor. As a result, the titer of MK-7 increased up to $86.48 \mathrm{mg} / \mathrm{L}$ [51]. Berenjian et al. (2014) optimized stirrer speed and aeration rate in a $3 \mathrm{~L}$ bioreactor for the production and recovery of $\mathrm{MK}-7$, resulting in increased titer of MK-7 up to $226 \mathrm{mg} / \mathrm{L}$ [52]. These results suggested that MK-7 production by wild-type B. subtilis natto strain improves by optimization of medium composition and fermentation conditions, followed by scale-up of fermentation. Interestingly, $\mathrm{Hu}$ et al. (2017) utilized surfactants to increase MK-7 production by the B. subtilis natto R127 [53]. The titer of MK-7 was $40.96 \mathrm{mg} / \mathrm{L}$ when $20 \mathrm{~g} / \mathrm{L}$ of soybean oil was used as a surfactant [53]. Among the surfactants they used, a non-ionic surfactant such as soybean oil was more effective than other ionic surfactants for MK-7 production [53].

Table 1. Production of vitamin K2 using wild-type microorganisms.

\begin{tabular}{|c|c|c|c|c|c|c|c|c|}
\hline Class & Strain & Strategy & $\begin{array}{l}\text { Carbon } \\
\text { Source }\end{array}$ & $\begin{array}{l}\text { Menaquinone } \\
\text { Type }\end{array}$ & $\begin{array}{l}\text { Fermentation } \\
\text { Time }\end{array}$ & Titer & Extraction & Reference \\
\hline \multirow{14}{*}{ Bacillus spp. } & Bacillus subtilis natto & $\begin{array}{l}\text { Optimization of medium and } \\
\text { fermentation condition }\end{array}$ & Glycerol & MK-7 & 6 days & $62.32 \mathrm{mg} / \mathrm{L}$ & By aqueous medium & [49] \\
\hline & Bacillus subtilis natto & $\begin{array}{l}\text { Carbon source addition } \\
\text { during fermentation }\end{array}$ & Glycerol & MK-7 & 6 days & $68.6 \mathrm{mg} / \mathrm{L}$ & By aqueous medium & [50] \\
\hline & Bacillus subtilis natto & Fed-batch fermentation & Glycerol & MK-7 & 6 days & $86.48 \mathrm{mg} / \mathrm{L}$ & By aqueous medium & [51] \\
\hline & Bacillus subtilis natto & $\begin{array}{l}\text { Optimization of stirrer speed and } \\
\text { aeration rate }\end{array}$ & Glycerol & MK-7 & $100 \mathrm{~h}$ & $226 \mathrm{mg} / \mathrm{L}$ & By aqueous medium & [52] \\
\hline & Bacillus natto R127 & $\begin{array}{l}\text { Optimization of medium } \\
\text { Supplementation of surfactant }\end{array}$ & Glycerol & MK-7 & $24 \mathrm{~h}$ & $40.96 \mathrm{mg} / \mathrm{L}$ & By aqueous medium & [53] \\
\hline & Bacillus subtilis natto $\mathrm{F} 2$ & Static fermentation & Glycerol & MK-7 & $96 \mathrm{~h}$ & $35.5 \mathrm{mg} / \mathrm{L}$ & By fermentation broth & [54] \\
\hline & Bacillus subtilis natto (NF1) & $\begin{array}{l}\text { Biofilm reactors (Plastic } \\
\text { composite support) } \\
\text { Optimization of medium }\end{array}$ & Glucose & MK-7 & $144 \mathrm{~h}$ & $20.5 \mathrm{mg} / \mathrm{L}$ & By aqueous medium & [55] \\
\hline & Bacillus subtilis natto (NF1) & $\begin{array}{c}\text { Biofilm reactors (Plastic } \\
\text { composite support) } \\
\text { Optimization of fermentation condition }\end{array}$ & Glucose & MK-7 & $144 \mathrm{~h}$ & $18.45 \mathrm{mg} / \mathrm{L}$ & By aqueous medium & [56] \\
\hline & Bacillus subtilis natto (NF1) & $\begin{array}{l}\text { Biofilm reactors (Plastic } \\
\text { composite support) } \\
\text { Fed-batch fermentation }\end{array}$ & Glucose & MK-7 & $288 \mathrm{~h}$ & $28.7 \mathrm{mg} / \mathrm{L}$ & By aqueous medium & [57] \\
\hline & Bacillus subtilis natto (NF1) & $\begin{array}{l}\text { Biofilm reactors } \\
\text { Biofilm reactors (Plastic }\end{array}$ & Glycerol & MK-7 & $144 \mathrm{~h}$ & $12.09 \mathrm{mg} / \mathrm{L}$ & By aqueous medium & [58] \\
\hline & Bacillus subtilis natto (NF1) & $\begin{array}{l}\text { composite support) } \\
\text { Optimization of medium }\end{array}$ & Glycerol & MK-7 & $144 \mathrm{~h}$ & $14.7 \mathrm{mg} / \mathrm{L}$ & By aqueous medium & [59] \\
\hline & Bacillus subtilis natto (NF1) & $\begin{array}{l}\text { Fermentation in bottle } \\
\text { Optimization of medium }\end{array}$ & Glycerol & MK-7 & $96 \mathrm{~h}$ & $32.5 \mathrm{mg} / \mathrm{L}$ & By aqueous medium & [60] \\
\hline & & Static fermentation & Glucose & MK-7 & $96 \mathrm{~h}$ & $14.6 \mathrm{mg} / \mathrm{L}$ & By aqueous medium & \\
\hline & Bacillus subtilis natto & Optimization of aeration and agitation & Milk medium & MK-7 & $72 \mathrm{~h}$ & $3.54 \mathrm{mg} / \mathrm{L}$ & By aqueous medium & [61] \\
\hline
\end{tabular}


Table 1. Cont.

\begin{tabular}{|c|c|c|c|c|c|c|c|c|}
\hline Class & Strain & Strategy & $\begin{array}{l}\text { Carbon } \\
\text { Source }\end{array}$ & $\begin{array}{l}\text { Menaquinone } \\
\text { Type }\end{array}$ & $\begin{array}{l}\text { Fermentation } \\
\text { Time }\end{array}$ & Titer & Extraction & Reference \\
\hline \multirow{7}{*}{ Bacillus spp. } & Bacillus subtilis NCIM 2708 & Optimization of medium & $\begin{array}{l}\text { Glycerol, } \\
\text { mannitol }\end{array}$ & MK-7 & $24 \mathrm{~h}$ & $39.039 \mathrm{mg} / \mathrm{g}$ & By soybean samples & [62] \\
\hline & Bacillus subtilis ATCC 6633 & Iron oxide nanoparticles coated & Glycerol & MK-7 & $108 \mathrm{~h}$ & $37.36 \mathrm{mg} / \mathrm{L}$ & By aqueous medium & [63] \\
\hline & Bacillus amyloliquefaciens & Optimization of medium and & Glycerol & MK-4 & $36 \mathrm{~h}$ & $0.76 \mathrm{mg} / \mathrm{g}$ & Fermented Cheonggukjang & [64] \\
\hline & КСТC 11712BP & fermentation condition & Glycerol & MK-7 & $36 \mathrm{~h}$ & $11.71 \mathrm{mg} / \mathrm{g}$ & Fermented Cheonggukjang & [64] \\
\hline & & Liquid-state fermentation & Glycerol & MK-7 & $168 \mathrm{~h}$ & $52.9 \mathrm{mg} / \mathrm{L}$ & By aqueous medium & \\
\hline & Bacillus velezensis ND & Biofilm-based fermentation & Glycerol & MK-7 & $144 \mathrm{~h}$ & $73.3 \mathrm{mg} / \mathrm{L}$ & By fermentation broth & [65] \\
\hline & & Solid-state fermentation & Glycerol & MK-7 & $96 \mathrm{~h}$ & $150.02 \mathrm{mg} / \mathrm{Kg}$ & By fermentation broth & \\
\hline \multirow{5}{*}{$\begin{array}{l}\text { Lactic acid } \\
\text { bacteria }\end{array}$} & $\begin{array}{l}\text { Lactococcus lactis ssp. cremoris } \\
\text { YIT } 2011\end{array}$ & Batch fermentation & Glucose & $\begin{array}{l}\text { MK-7, MK- } 8, \\
\text { MK-9 }\end{array}$ & $48 \mathrm{~h}$ & $534 \mathrm{nmol} / \mathrm{L}$ & $\begin{array}{l}\text { By cell using chloroform } \\
\text { and methanol }\end{array}$ & {$[66]$} \\
\hline & $\begin{array}{c}\text { Lactococcus lactis ssp. lactis } \\
\text { YIT } 2027\end{array}$ & Batch fermentation & Glucose & $\begin{array}{l}\text { MK-8, MK-9, } \\
\text { MK-10 }\end{array}$ & $48 \mathrm{~h}$ & $717 \mathrm{nmol} / \mathrm{L}$ & $\begin{array}{l}\text { By cell using chloroform } \\
\text { and methanol }\end{array}$ & [66] \\
\hline & Leuconostoc lactis YIT 3001 & Soymilk fermentation & Soy milk & $\begin{array}{l}\text { MK-7, MK-8, } \\
\text { MK-9, MK-10 }\end{array}$ & $48 \mathrm{~h}$ & $2.60 \mathrm{nmol} / \mathrm{L}$ & $\begin{array}{l}\text { By soymilk culture using } \\
\text { chloroform and methanol }\end{array}$ & \\
\hline & Lactobacillus fermentum LC272 & Batch fermentation & Glucose & MK-4 & $48 \mathrm{~h}$ & $0.18 \mathrm{mg} / \mathrm{L}$ & $\begin{array}{l}\text { By cell using hexane and } \\
\text { methanol }\end{array}$ & [67] \\
\hline & $\begin{array}{l}\text { Lactococcus lactis ssp. cremoris } \\
\text { MG1363 }\end{array}$ & $\begin{array}{l}\text { Optimization of temperature, carbon } \\
\text { source, aeration, and mode of } \\
\text { energy metabolism }\end{array}$ & Trehalose & $\begin{array}{l}\text { MK-5, MK-6, } \\
\text { MK-7, MK-8, } \\
\text { MK-9, MK-10 }\end{array}$ & $48 \mathrm{~h}$ & $\begin{array}{l}\text { 5.2-fold increase } \\
\text { compared to the } \\
\text { control }(90 \mathrm{nmol} / \mathrm{L} \\
\text { medium) }\end{array}$ & $\begin{array}{l}\text { By cell using hexane and } \\
\text { 2-propanol }\end{array}$ & [68] \\
\hline \multirow[b]{3}{*}{ Others } & Flavobacterium meningosepticum & Changing extraction solvent & Glycerol & $\begin{array}{l}\text { MK-4, MK-5, } \\
\text { MK-6 }\end{array}$ & 6 days & $1.88 \mathrm{mg} / \mathrm{g} \mathrm{DCW}$ & By cell using methanol & [69] \\
\hline & Flavobacterium sp. M1-14 & $\begin{array}{l}\text { Using different surfactant } \\
\text { with ultrasound }\end{array}$ & Glycerol & MK & 9 days & $30.03 \mathrm{mg} / \mathrm{L}$ & In aqueous medium & [70] \\
\hline & $\begin{array}{l}\text { Enterobacter agglomerans } \\
\text { Serratia marcescens } \\
\text { Enterococcus faecium }\end{array}$ & Isolated from neonatal fecal flora & $\begin{array}{l}\text { Tryptone soy } \\
\text { broth powder }\end{array}$ & MK-4 & $72 \mathrm{~h}$ & ND & $\begin{array}{l}\text { By cell using methanol and } \\
\text { chloroform }\end{array}$ & [71] \\
\hline
\end{tabular}

ND: not determined; DCW: dry cell weight.

Mahdinia et al. used a biofilm reactor with plastic composite supports (PCS) to produce MK-7 by the B. subtilis natto [54-59]. Using biofilm reactor is a good strategy for enhanced production of MK-7 and reduced lag phase periods with optimization of fermentation conditions [72]. When the fermentation medium containing glucose was optimized, MK-7 produced up to $28.7 \mathrm{mg} / \mathrm{L}$ [54]. When the fermentation medium containing glycerol was used, MK-7 titer was $14.7 \mathrm{mg} / \mathrm{L}$ [59]. A study performed a static fermentation using McCartney bottles, resulting in increased titer of MK-7 to $32.5 \mathrm{mg} / \mathrm{L}$ [60]. In the MK-7 production modeling study, the authors predicted and confirmed that MK-7 production by the wild-type B. subtilis natto exhibited a mixed-metabolite pattern [73]. Donya Novin et al. (2020) produced MK-7 from a newly isolated B. subtilis natto using the medium containing milk in a bioreactor [61]. The maximum titer of MK-7 reached $3.54 \mathrm{mg} / \mathrm{L}$ through optimization of agitation and aeration as the key operating conditions [61].

Other than B. subtilis natto strain, B. subtilis NCIM 2708 was used to produce MK-7 by solid-state fermentation [62]. When the medium composition and fermentation condition were optimized, the titer of MK-7 led to $39.039 \mathrm{mg} / \mathrm{L}$ for $24 \mathrm{~h}$ of fermentation [62]. Another approach to increase MK-7 production by $B$. subtilis was using iron oxide nanoparticles coated with 3-aminopropultriethoxysilane (IONs@APTES), which might enhance secretion of MK-7 out of the Bacillus cells [63]. B. subtilis ATCC 6633 was utilized to produce MK-7 in the medium containing $200 \mathrm{mg} / \mathrm{mL}$ IONs@APTES, resulting in the maximum titer of MK-7 up to $37.36 \mathrm{mg} / \mathrm{L}$ [63].

Other Bacillus strains were also used for menaquinone production. One of the examples was B. amyloliquefaciens KCTC 11712BP used for manufacturing Cheonggukjang with high concentration of menaquinone [64]. Using $4 \%$ glycerol supplemented to Cheonggukjang, the titer of total menaquinone in Cheonggukjang was $12.47 \mathrm{mg} / \mathrm{g}(0.76 \mathrm{mg} / \mathrm{g}$ of MK-4 and $11.71 \mathrm{mg} / \mathrm{g}$ of MK-7) [64]. B. velezensis ND was also tested for MK-7 production by optimization of fermentation conditions with nitrogen source [65]. The MK-7 production varied with fermentation processes, resulting in $52.9 \mathrm{mg} / \mathrm{L}$ by liquid-state fermentation, $73.3 \mathrm{mg} / \mathrm{L}$ by biofilm fermentation, and $150.02 \mathrm{mg} / \mathrm{kg}$ by solid-state fermentation [65]. These results suggested that wild-type Bacillus strains naturally produce vitamin $\mathrm{K}$ at a high concentration. The highest titer of MK-7 by the wild-type Bacillus strain was $226 \mathrm{mg} / \mathrm{L}$ after $100 \mathrm{~h}$ of fermentation [52]. Vitamin K production can be improved by bioprocessing engineering, such as optimization of fermentation conditions. Some of the Bacillus strains can be utilized for industrial production of vitamin $\mathrm{K}$ through large-scale fermentation. 


\subsection{Lactic Acid Bacteria}

Multiple forms of menaquinone have been found in fermented dairy foods, which may be produced by lactic acid bacteria (LAB) (Table 1) [74]. In cheese fermentation, Lactoccocus ssp. and propionibacteria are known to produce menaquinones [75,76]. Foodrelated LAB, as well as members of human gut microbiota such as Bifidobacterium, can synthesize and provide vitamin $\mathrm{K}$ to the human body [71,77].

Morishita et al. (1999) quantified menaquinones produced by LAB, including Lactococcus ssp., Leuconostoc ssp., Enterococcus faecalis, Lactobacillus ssp., Streptococcus ssp., and Bifidobacterium ssp. [66]. The authors conducted fermentations using both growth medium and soymilk. The batch fermentations of LAB were performed with the Rogosa medium containing $20 \mathrm{~g} / \mathrm{L}$ glucose at $30^{\circ} \mathrm{C}$ for $48 \mathrm{~h}$. The menaquinone was extracted from lyophilized cells from the growth medium and from soymilk culture using a mixture of chloroform and methanol. Among the LAB strains examined in this study, Lactococcus lactis subsp. cremoris, Lactococcus lactis subsp. lactis, and Leuconostoc lactis were selected as high producers of menaquinone [66]. Menaquinone content of L. cremoris YIT 2011 was total $534 \mathrm{nmol} / \mathrm{g}$ lyophilized cells, consisting of MK-7 to MK-9. The highest menaquinone content was $717 \mathrm{nmol} / \mathrm{g}$ lyophilized cells of L. lactis YIT 2027, consisting of MK-8 to MK-10. In the soymilk fermentation, the highest menaquinone content was $2.60 \mathrm{nmol} / \mathrm{g}$ of the soymilk culture by Leuconostoc lactis YIT 3001 strain, consisting of MK-7 to MK-10 [66]. Liu et al. (2019) increased the titer of menaquinone by Lactococcus lactis subsp. cremoris MG1363 by optimizing temperature, carbon source, aeration, and mode of energy [68]. The MG1363 strain produced $90 \mathrm{nmol} / \mathrm{L}$ of total menaquinone (MK-5 to MK-10) extracted from the medium by a static fermentation using a growth medium containing glucose at $30^{\circ} \mathrm{C}$ for $48 \mathrm{~h}$. When the aerobic fermentation at $120 \mathrm{rpm}$ and $30^{\circ} \mathrm{C}$ for $48 \mathrm{~h}$ was performed using trehalose as a carbon source, the MG1363 strain achieved a 5.2-fold increase in menaquinone production [68].

Lim et al. (2011) confirmed menaquinone production by Lactobacillus fermentum LC272 in different culture media [67]. The MK-4 titer by the LC272 strain was $184.94 \mu \mathrm{g} / \mathrm{L}$ in the modified Rogosa medium, and $63.93 \mu \mathrm{g} / \mathrm{L}$ in reconstituted skim milk after extraction [67]. These results suggested that wild-type LAB strains could produce various menaquinone subtypes with decent titers. The shorter fermentation time was remarkable in menaquinone production by LAB. However, the titers of menaquinones produced by LAB were below those of Bacillus strains, when it was considered that the wild-type B. subtilis natto strain produced $226 \mathrm{mg} / \mathrm{L}(346.2 \mu \mathrm{mol} / \mathrm{L})$ of MK-7 [52]. Other LAB strains can be isolated for higher production titer of vitamin $\mathrm{K}$. Some of the LAB strains may be developed as a probiotic strain producing vitamin $\mathrm{K}$ in human gut.

\subsection{Other Microorganisms}

Besides Bacillus and LAB, other bacteria also produce vitamin $\mathrm{K}$. Flavobacterium meningosepticum is one of the menaquinone-producing bacteria (Table 1) [69]. F. meningosepticum is a Gram-negative aerobic bacillus, nonmotile, oxidase-positive bacteria found in soil, freshwater, and saltwater [78]. F. meningosepticum is difficult to be engineered because of the lack of biotechnological tools compared to other model microorganisms. Rather than strain engineering, various extraction methods have been applied to increase menaquinone production from $F$. meningosepticum. Fang et al. (2019) used a surfactant and ultrasound during fermentation to increase extracellular menaquinone production [70]. The use of surfactant and ultrasound was used to improve the productivity of target products from biotechnological processes without using chemical agents increasing cell membrane permeability [79]. The authors conducted screening of surfactants that could increase the yield of menaquinone, including Triton-100, sodium dodecyl benzene sulfonate, Tween-80, and polyoxyethyleneoleyl (POE) [70]. When they added 1\% POE to the medium, F. meningosepticum produced the highest yield of menaquinone, reaching up to $15.95 \mathrm{mg} / \mathrm{L}$. Ultrasound treatment was further treated with $\mathrm{POE}$, resulting in enhanced menaquinone production up to $30.03 \pm 1.42 \mathrm{mg} / \mathrm{L}$ in an aqueous medium [70]. These results suggested 
that chemical and physical methods, such as ultrasound and surfactant, might affect cellular permeability by forming pores temporarily in the cell membrane, thereby increasing the secretion of target metabolites out of the cells.

Wei et al. (2018) attempted to overproduce menaquinone through extraction from the cultured cells of $F$. meningosepticum by using various organic solvents. The authors cultured F. meningosepticum aerobically in $18 \mathrm{~L}$ of medium containing glycerol for 6 days, and harvested cells followed by freeze-drying. The dried cells of $F$. meningosepticum were treated with $5 \mathrm{~mL}$ of organic solvents including methanol, absolute ethyl alcohol, acetone, n-butanol, dichloromethane, isopropanol, acetic acid, acetonitrile, n-hexane, and petroleum ether. They finally selected methanol as an efficient organic solvent and produced menaquinone up to $1.88 \mathrm{mg} / \mathrm{g}$ DCW from F. meningosepticum [69].

Other than F. meningosepticum, many efforts have been made for finding a novel microbial strain that produces vitamin K naturally. Cooke et al. (2006) reported vitamin Kproducing bacteria isolated from the neonatal fecal flora, including Enterobacter agglomerans, Serratia marcescens, and E. faecium [71]. The authors confirmed MK-4 production by the newly isolated strains in fermentation medium by LC/MS analysis [71]. Similarly, various intestinal anaerobic bacteria isolated from fecal samples have been evaluated for vitamin $\mathrm{K}$ production capacity [80]. Commensal bacteria, including Bacteriodes ssp., Eubacterium lentum, Veillonella ssp., Wolinella ssp., Actinomyces ssp., Arachnia propionica, and Propionibacterium ssp., were confirmed as menaquinone producers [81]. These results suggested that a wide variety of bacteria can contribute vitamin K production. However, industrial fermentation of vitamin $\mathrm{K}$ requires a decent titer and productivity of the host strains for economical production. Additionally, the host strain may be required to have a GRAS status for production of microbial-derived vitamin $\mathrm{K}$ used as a food supplement.

\section{Production of Vitamin K Using Engineered Microorganisms}

\subsection{Engineered Bacillus}

Strain engineering strategies, including random mutagenesis and rational design, can be used to increase the titer, yield, and productivity of target chemicals from fermentation. Various vitamin K-producing Bacillus strains have been engineered to increase vitamin production (Table 2). Random mutagenesis using a chemical agent or physical treatment can be first used for the construction of mutant strains exhibiting desirable phenotypes [82]. The well-known chemical mutagen, N-methyl-N'-nitro-N-nitrosoguanidine (NTG), which causes alkylation of guanine or thymine, has been used for the construction of Bacillus mutants to overproduce vitamin K $[83,84]$. Along with the chemical mutagens, various analogs of vitamin K2 precursors such as 1-hydroxy-2-naphthoic acid (HNA) have been treated for generating Bacillus mutants with increased metabolic flux to vitamin $\mathrm{K}$ biosynthesis [84,85]. The diphenylamine (DPA), which inhibits the biosynthesis of naphthoquinone ring, can also generate the mutant strains overproducing vitamin $\mathrm{K}[74,77,78]$. Sato, T., et al. (2001) used NTG together with DPA to construct the mutant strain of B. subtilis. The resulting D200-41 strain produced $19.6 \mathrm{mg} / \mathrm{L}$ of vitamin $\mathrm{K} 2$ in a $500 \mathrm{~mL}$ flask fermentation and $62.1 \mathrm{mg} / \mathrm{L}$ of vitamin $\mathrm{K} 2$ in static fermentation for 5 days after optimization of carbon and nitrogen source in the growth medium [83]. Similarly, the construction of the Bacillus mutant released from feedback inhibition by aromatic amino acids was effective to enhance the vitamin K biosynthetic pathways, since the aromatic amino acids share their biosynthetic pathways with vitamin K [85]. 
Table 2. Production of vitamin K2 using engineered microorganisms.

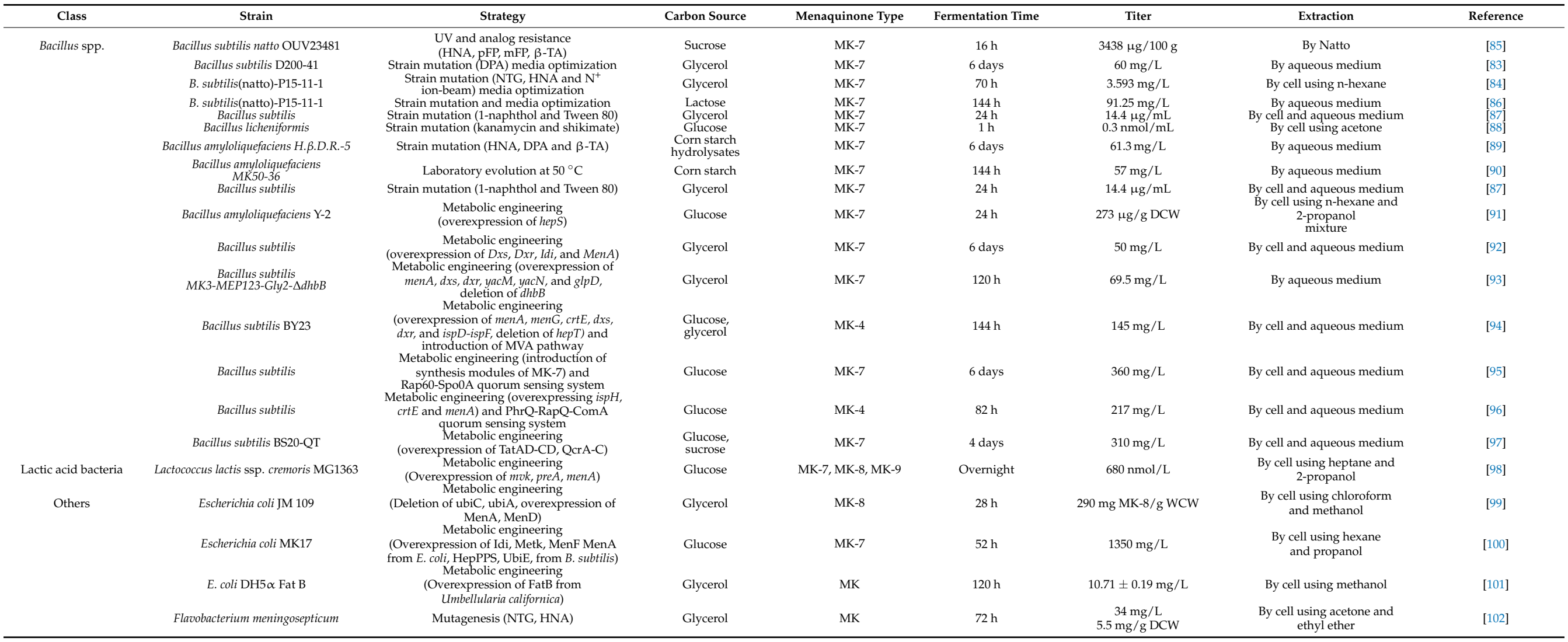

HNA: 1-hydroxy-2-naphthoic acid; pFP: p-fluoro-D,L-phenylalanine; mFP: m-fluoro-D,L-phenylalanine; $\beta$-TA: $\beta$-2-thienylalanine; DPA: diphenylamine; NTG: N-methyl-N'-nitroN-nitrosoguanidine. 
Physical methods for random mutagenesis such as $\mathrm{UV}$ and $\mathrm{N}^{+}$ion-beam were also used for generating Bacillus mutants with increased vitamin $\mathrm{K}$ production $[84,85]$. Tsukamoto and Kasai et al. (2001) attempted to generate several mutant strains based on the wild-type B. subtilis O-2 strain isolated from Natto by the UV treatment together with analogs of vitamin K precursors [85]. The resulting mutant B. subtilis OUV23481 was utilized for making Natto containing vitamin K2 up to $1.719 \mu \mathrm{g} / 100 \mathrm{~g}$ of Natto, which was 1.7 times higher than that made by the parent strain [85]. Similarly, Song, J., et al. (2014) used NTG and HNA with $\mathrm{N}^{+}$ion-beam treatment for construction of the mutant strain based on the wild-type B. subtilis BN2-6 strain isolated from Natto [84]. The resulting strain BN-P15-11-1 produced $2.5 \mathrm{mg} / \mathrm{L}$ of vitamin $\mathrm{K} 2$, which was $166 \%$ higher than that of the parent strain. Further optimization of the fermentation medium increased vitamin $\mathrm{K} 2$ production up to $3.593 \mathrm{mg} / \mathrm{L}$ by the BN-P15-11-1 strain [84]. Wang et al. (2018) optimized the nitrogen, carbon, and inorganic salt sources in culture media for increased MK-7 production using the $B$. subtilis BN-P15-11-1 strain [86]. The authors found the optimum composition of medium, which contained soybean curd residue, soya peptone, lactose, and $\mathrm{K}_{2} \mathrm{HPO}_{4}$. As a result, the $B$. subtilis BN-P15-11-1 strain produced about $45 \mathrm{mg} / \mathrm{L}$ of $\mathrm{MK}-7$ in the optimized medium in a 3.7 L bioreactor. When the authors optimized oxygen supply conditions using two-stage dissolved oxygen (DO) strategy, the BN-P15-11-1 strain produced $91.25 \mathrm{mg} / \mathrm{L}$ of MK-7 in a 3.7 L bioreactor [86]. Puri et al. (2015) constructed the mutant strain based on the B. subtilis using 1-naphthol [87]. The 1-naphthol mutant strain produced $12.5 \mu \mathrm{g} / \mathrm{mL}$ of MK-7 in $100 \mathrm{~mL}$ flask fermentation for $24 \mathrm{~h}$ and $14.4 \mu \mathrm{g} / \mathrm{mL}$ of MK-7 in $100 \mathrm{~mL}$ flask fermentation in the presence of Tween 80 for $24 \mathrm{~h}$ [87]. These results suggested that vitamin $\mathrm{K}$ production by $B$. subtilis strains can be improved by various random mutagenesis strategies using chemical and physical treatments.

Other Bacillus strains than B. subtilis have been engineered for vitamin K production. Goodman et al. (1976) constructed the menaquinone-deficient mutant strain based on wild-type Bacillus licheniformis using kanamycin and shikimate [88]. The resulting strain produced $0.3 \mathrm{nmol} / \mathrm{mg}$ of $\mathrm{MK}-7$, which was lower than the titer of MK-7 produced by wild-type strain (0.38 nmol/mg) [88]. Xu, J. Z., and Zhang, W. G. (2017) identified Bacillus amyloliquefaciens Y-2 strain from douche, a Chinese salted black bean food [89]. The authors constructed B. amyloliquefaciens H.ß.D.R.-5 mutant strain based on the wild-type Y-2 strain through multi-round random mutagenesis using HNA, DPA, and $\beta$-thienylalanine ( $\beta$ TA) for generating analog resistance. The H.ß.D.R.-5 mutant produced $61.3 \mathrm{mg} / \mathrm{L}$ of MK-7 in maize meal hydrolysate medium using a 7 L fermenter [89]. Recently, Liu, N. et al. (2021) used the H.ß.D.R.-5 mutant to create another B. amyloliquefaciens mutant having a high $\alpha$-amylase activity through adaptive evolution by temperature-induced mutagenesis at a high growth temperature. The resulting heat-resistant mutant MK50-36 produced $57 \mathrm{mg} / \mathrm{L}$ of MK-7 in corn starch medium for 6 days of fed-batch fermentation [90].

Along with random mutagenesis, rational strain engineering strategies such as metabolic engineering have been conducted to increase the MK-7 biosynthesis in Bacillus [92,93,95,96]. Over the past few years, the MK-7 biosynthesis pathway and many enzymes involved in biosynthesis have been studied, which facilitates metabolic engineering [30]. The biosynthesis pathways of menaquinone in Bacillus are categorized into three pathways: the methylerythritol phosphate (MEP) pathway, the shikimic acid (SA) pathway, and the menaquinone pathway (Figure 2). Several studies attempted to overexpress the pathway genes to increase vitamin K production in Bacillus. Xu, Yan et al. (2017) performed metabolic engineering study to construct an efficient B. amyloliquefaciens platform to produce MK-7 by overexpression of endogenous MK-7 biosynthetic pathway enzymes [91]. After the genetic analysis, six genes involved in the biosynthesis of the naphthoquinone ring were selected for overexpression to increase MK-7 production. The enzymes overexpressed individually in the Y-2 strain were DHNA octaprenyltransferase (MenA), o-succinylbenzoate synthase (MenD), osuccinylbenzoyl-coenzyme A synthetase (MenE), SHCHC synthase (MenH), and heptaprenyl diphosphate synthase (HepS) (Figure 2). Among these enzymes, overexpression of the HepS showed the greatest increase in MK-7 production, up to $273 \mu \mathrm{g} / \mathrm{g}$ DCW [91]. 


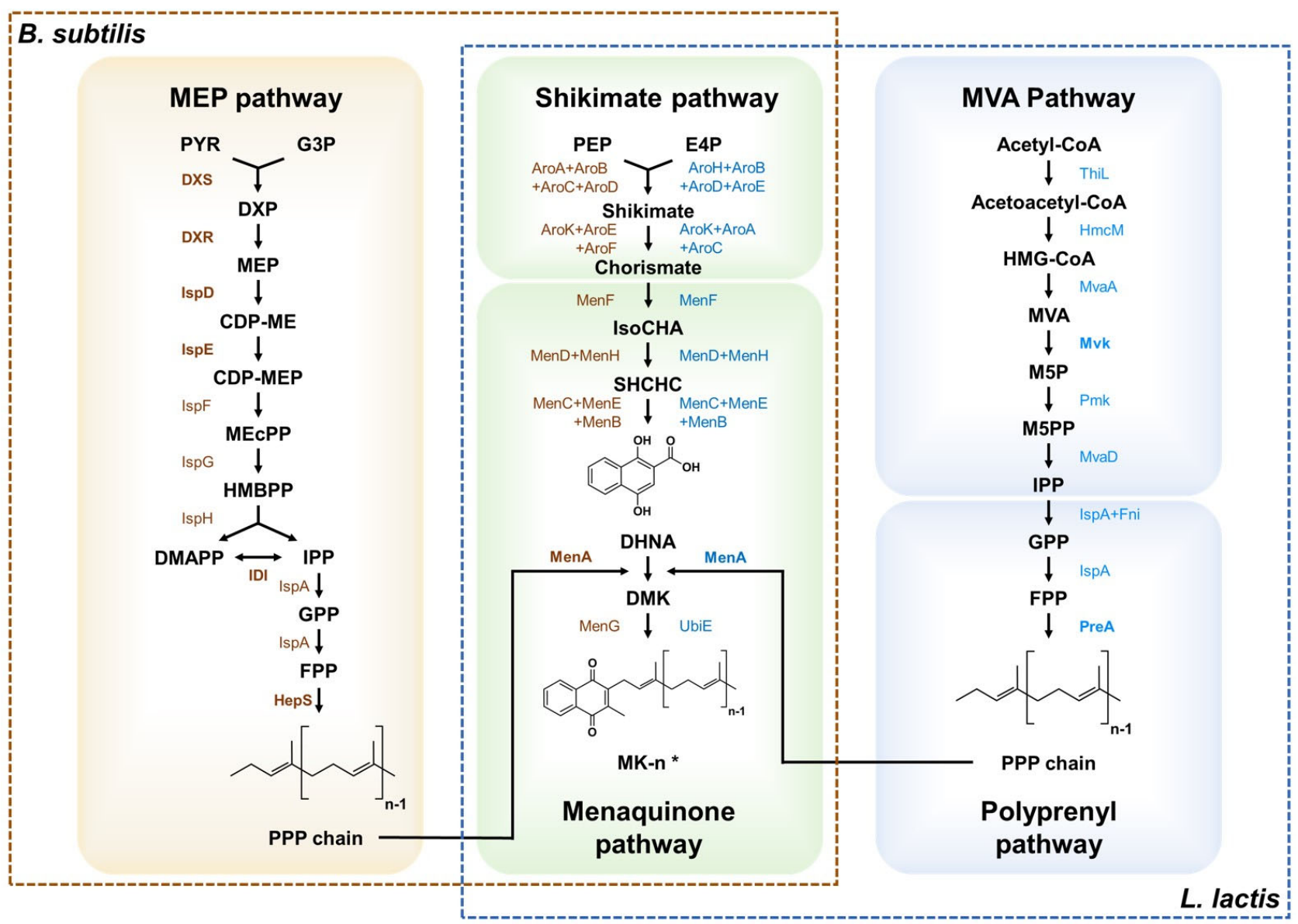

Figure 2. Biosynthetic pathway of menaquinone in Bacillus subtilis and Lactococcus lactis covered in this review. Metabolic pathways engineered in microorganisms for production of vitamin $\mathrm{K}$ were displayed. The prenyl chain structures are synthesized by the MEP pathway in B. subtilis and by the MVA pathway in L. lactis subsp. cremoris. The naphthoquinone ring structure is synthesized by the shikimate pathway and connected to side chains by the menaquinone pathway. The brown square with a dotted line refers to the pathway of menaquinone7 synthesizing in B. subtilis. The blue square with a dotted line refers to the pathway of menaquinones synthesizing in L. lactis subsp. cremoris. The enzymes in bold were overexpressed to increase vitamin K production in the previous studies. PYR, pyruvate; G3P, glycerol-3phosphate; DXP, 1-deoxyxylulose-5-phosphate; MEP, methyl-erythritol-4-diphosphate; CDP-ME, 4-(cytidine 5'-diphospho)-2-C-methylerythritol; CDP-MEP, 2-phospho-4-(cytidine 5'-diphospho)-2-Cmethylerythritol; MECPP, HMBPP,2-C-Methylerythritol 2,4-cyclodiphosphate; HMBPP,1-hydroxy2-methyl-2-butenyl 4-diphosphate; DMAPP, dimethylallyl diphosphate; IPP, isopentenyl diphosphate; GPP, geranyl diphosphate; FPP, farnesyl diphosphate; HPP, heptaprenyl diphosphate; PPP, polyprenyl diphosphate; $\mathrm{PEP}$, phosphoenolpyruvate; E4P, erythrose-4-phosphate; IsoCHA, isochorismate; SHCHC, 2-succinyl-6-hydroxy-2,4-cyclohexadiene-1-carboxylate; DHNA, 1,4-dihydroxy-2naphthoate; DMK, 2-demethylmeaquinone; MK-n, menaquinone-n; MVA, Mevalonate; M5P, Mevalonate 5-phosphate ;M5PP, 5-Diphosphomevalonate; [MEP pathway enzymes] DXS, 1-Deoxy-Dxylulose-5-phosphate synthase; DXR, 1-Deoxy-D-xylulose-5-phosphate reductoisomerase; IspD, 2-C-methyl-D-erythritol 4-phosphate cytidylyltransferase; IspE, 4-Diphosphocytidyl-2-C-methylD-erythritol kinase; IspF, 2-C-Methyl-D-erythritol 2,4-cyclodiphosphate synthase; IspG, 4-hydroxy3-methylbut-2-en-1-yl diphosphate synthase; IspH, 4-Hydroxyl-3-methylbut-2-enyl diphosphate reductase; IspA, Farnesyl diphosphate synthase; HepS, Heptaprenyl diphosphatesynthase component; 
[Shikimate pathway enzymes (B. subtilis)] AroA, 3-Deoxy-7-phosphoheptulonate synthase; AroB, 3-Dehydroquinate synthase; AroC, 3-Dehydroquinate dehydratase; AroD, Shikimate dehydrogenase; AroK, Shikimate kinase; AroE, 3-Phosphoshikimate 1-carboxyvinyltransferase; AroF, Chorismate synthase; [Shikimate pathway enzymes (L. lactis)] AroH, Phospho-2-dehydro-3-deoxyheptonate aldolase; AroB, 3-Dehydroquinate synthase; AroD, 3-Dehydroquinate dehydratase; AroE, Shikimate dehydrogenase; AroK, Shikimate kinase; AroA, 3-Phosphoshikimate 1-carboxyvinyltransferase; AroC, Chorismate synthase; [Menaquinone pathway enzymes] MenF, isochorismate synthase; MenD, 2-Succinyl-5-enolpyruvyl-6-hydroxy-3-cyclohexene-1-carboxylate synthase; MenH, Demethylmenaquinone methyltransferase; MenC, O-Succinylbenzoate synthase; MenE, O-SuccinylbenzoateCoA ligase; MenB, 1,4-Dihydroxy-2-naphthoyl-CoA synthase; MenA, 1,4-Dihydroxy-2-naphthoate heptaprenyltransferase; MenG, Demethylmenaquinone methyltransferase; UbiE, Demethylmenaquinone methyltransferase; [Mevalonate pathway enzymes] ThiL, 3-Ketoacyl-CoA thiolase; HmcM, Hydroxymethylglutaryl-CoA synthase; MvaA, Hydroxymethylglutaryl-CoA reductase; Mvk, Mevalonate kinase; Pmk, Phosphomevalonate kinase; MvaD, Diphosphomevalonate decarboxylase; IspA, Geranyltranstransferase; Fni, Isopentenyl-diphosphate delta-isomerase; PreA, Prenyl diphosphate synthase.

For systematic metabolic engineering, Yang, Cao et al. (2018) developed the modular system for overexpression of the biosynthetic pathway to increase MK-7 production by B. subtilis [93]. The authors categorized the MK-7 biosynthetic pathway into four modules: the MK-7 pathway (Module I), the shikimate (SA) pathway (Module II), the methylerythritol phosphate (MEP) pathway (Module III), and the glycerol metabolism pathway (Module IV). They overexpressed key enzymes in each module to increase metabolic flux to MK7 biosynthesis. The $B$. subtilis MK3 strain overexpressing the menA gene in Module I produced $6.6 \pm 0.1 \mathrm{mg} / \mathrm{L}$ of MK-7, which was a 2.1-fold increase when compared to the parent strain. However, overexpression of the $\operatorname{aro} A, \operatorname{aroD}$, and $\operatorname{aro} E$ in Module II reduced the MK-7 production in B. subtilis. The $d x s, d x r, y a c M$, and yacN genes in Module III were overexpressed in the MK3 strain, resulting in increased MK-7 production up to $12.0 \pm 0.1 \mathrm{mg} / \mathrm{L}$. Subsequently, the $g l p D$ gene in Module IV was overexpressed to enhance glycerol utilization in B. subtilis, resulting in $13.7 \pm 0.2 \mathrm{mg} / \mathrm{L}$ of MK-7 production. After the $d h b B$ gene was deleted to block the competitive biosynthetic pathway, the final strain of B. subtilis produced $69.5 \mathrm{mg} / \mathrm{L}$ of MK-7 after $144 \mathrm{~h}$ fermentation in a 2 L baffled flask [93]. Similarly, Ma, Y., et al. (2019) overexpressed the rate-limiting enzymes including MenA, Dxs, Dxr, and Idi involved in menaquinone and MEP biosynthetic pathways in B. subtilis [92]. The recombinant $B$. subtilis overexpressing the men $A-d x s-d x r$-idi gene cluster showed the highest MK-7 production up to $50 \mathrm{mg} / \mathrm{L}$, which was more than 5 times higher than that of the wild-type strain [92].

Yuan et al. (2020) tried to overproduce MK-4 by B. subtilis through combinatorial engineering [94]. The authors overexpressed the menA, men $G$, and crtE genes from Synechocystis sp. PCC 6803 involved in MK-4 synthesis under the strong constitutive promoter P43, resulting in $8.1 \mathrm{mg} / \mathrm{L}$ of MK-4. After the knockout of hepT gene, which catalyzes the conversion of farnesyl diphosphate to heptaprenyl diphosphate, simultaneous overexpression of $d x s$, $d x r$, and ispD-ispF genes in MEP pathway increased the titer of MK-4 up to $78.1 \mathrm{mg} / \mathrm{L}$. Moreover, overexpression of the heterogeneous MVA and menaquinone pathway genes further increased the titer of MK-4 up to $120.1 \mathrm{mg} / \mathrm{L}$ in a flask fermentation and $145 \mathrm{mg} / \mathrm{L}$ in a 3-L fed-batch fermentation [94].

Interestingly, various quorum sensing (QS) systems have been utilized to increase menaquinone production in B. subtilis. The QS-based dynamic regulation has been used for controlling gene expression by cell density changes without using inducers. The authors developed a modular Phr60-Rap60-Spo0A QS system which allows dynamic control of MK7 synthesis in B. subtilis in response to cell growth. The QS system was applied to engineer Bacillus subtilis which has the synthesis modules of MK-7, resulting in the BS20 strain. The BS20 strain produced $360 \mathrm{mg} / \mathrm{L}$ of MK-7, which was a 40-fold improvement [95]. Recently, Cui et al. (2020) used the B. subtilis BS20 strain to construct another engineered strain [97]. 
Since the authors confirmed that the genes related to cell membrane components could affect the MK-7 production, they overexpressed signal transduction protein (TatAD-CD) and methyl phenol cytochrome $c$ reductase (QcrA-C) in the BS20 strain. The resulting BS20-QT strain produced $310 \mathrm{mg} / \mathrm{L}$ of MK-7 [97]. Another study reported the increased production of MK-4 in B. subtilis using the QS system [96]. The authors developed the PhrQRapQ-ComA QS system and introduced it into the recombinant B. subtilis, overexpressing the ispH, crtE, and menA for dynamic control of MK-4 biosynthesis by the QS system. The resulting BC04 strain produced $217 \mathrm{mg} / \mathrm{L}$ of MK-4 in a 3L fermenter [96]. These results suggested that cell growth and efficient synthesis of the vitamin $\mathrm{K}$ in $B$. subtilis can be dynamically balanced by the QS system, resulting in increased vitamin $\mathrm{K}$ production. The highest MK-7 titer by the engineered Bacillus was $360 \mathrm{mg} / \mathrm{L}$ in $82 \mathrm{~h}$ of fermentation, which is higher than the maximum titer by the wild-type Bacillus (226 mg/L in $100 \mathrm{~h}$ ) [95]. These results suggested that the titer of $\mathrm{MKs}$ can be further increased by strain engineering.

\subsection{Engineered Lactic Acid Bacteria}

Lactococcus lactis is known to produce a range of menaquinone subtypes. Additionally, L. lactis has been used as a microbial cell factory platform of LAB. The biosynthesis pathway of menaquinone in L. lactis was categorized into four pathways: the mevalonate pathway, the polyprenyl pathway, the shikimate pathway, and the menaquinone pathway [98]. To increase menaquinone production in L. lactis, Bøe et al. (2020) overexpressed key enzymes of the menaquinone biosynthetic pathway in L. lactis, including mevalonate kinase $(m v k)$, prenyl diphosphate synthases (preA), isochorismate synthase (menF), and DHNA polyprenyltransferase (menA) (Figure 2) [98]. Combined expression of $m v k$, preA, and menA in L. lactis subsp. cremoris NZ9000 produced $680 \mathrm{nmol} / \mathrm{L}$ of total menaquinones (MK-7, MK-8, and MK-9). When the resulting strain was further utilized for milk fermentation, the menaquinone content (MK-7 to MK-9) in the fermented milk was around $700 \mathrm{nmol} / \mathrm{L}$, which was a 3-fold increase compared to that fermented by the wild type strain (Table 2) [98].

Genetic engineering of LAB strains for vitamin K production has not been widely attempted due to the lack of toolbox and difficulty in strain engineering when compared to other host strains such as Bacillus and E. coli. Many efforts have been made to develop genetic engineering tools for $\mathrm{LAB}$, including various expression systems and secretion systems $[103,104]$. CRISPR-Cas systems for LAB have been also developed for Limosilactobacillus reuteri (formerly known as Lactobacillus reuteri) [105], Lactobacillus gasseri [106], Leuconostoc citreum [107], Bifidobacteria [108], and other strains of LAB [109]. Recent advances in genetic engineering toolbox can facilitate vitamin K production by LAB through rational engineering.

\subsection{Other Engineered Microorganisms}

E. coli has been considered as a microbial cell factory platform because of its wellestablished engineering tool and fast-growing properties [110-112]. E. coli can synthesize ubiquinone-8 (Q-8) under aerobic conditions and menaquinone-8 (MK-8) under anaerobic conditions [113-115]. Kong et al. (2011) tried to increase the production of OPP and chorismite, which are precursors for the tail and head structures of menaquinone, respectively [99]. To select the suitable host for MK-8 production, six strains of E. coli (JM109, Top10, DH5a, MG1655, SURE, and MDS42) were evaluated for MK-8 and Q-8 production. The JM109 strain showing the highest content of 55-57 mg MK-8/g WCW (wet cell weight) was selected as a host strain for further metabolic engineering. Overexpression of endogenous IspA, DXR, or IDI increased MK-8 production up to 2-fold. Since MK-8 and Q-8 share chorismate as a precursor for their head polar part, the authors deleted UbiA and UbiC that were involved in the synthesis of Q-8. The Q-8-deficient ubiCA mutant enhanced MK-8 content by $30 \%$ compared to wild-type E. coli. When MenA was further overexpressed, the MK-8 content was enhanced by 5-fold (290 mg MK-8/g WCW) when compared to the wild-type E. coli (Table 2) [99]. 
E. coli can be used to produce MK-7, even if E. coli mainly produces Q-8, MK-8, and demethylmenaquinone-8 (DMK-8) [116]. Recently, Gao et al. (2021) produced MK7 by E. coli through systematic metabolic engineering [100]. The authors categorized the MK-7 biosynthesis pathway of E. coli into three modules: the MVA pathway, the DHNA pathway, and the MK-7 pathway, and optimized each pathway to enhance MK-7 production. They first overexpressed the isopentenyl diphosphate isomerase (Idi) enzyme from different species, Saccharomyces cerevisiae, Populus trichocarpa, and E. coli K12, which are involved in the supply of IPP/DMAPP precursor for the biosynthesis of MK-7. Next, they overexpressed the endogenous MenA and exogenous UbiE together with the heptaprenyl pyrophosphate synthase (HepPPS) from B. subtilis which enhanced MK-7 production up to $70 \mu \mathrm{M}$ [100]. The HepPPS is an important key enzyme, allowing MK-7 production in E. coli under aerobic conditions. Finally, the DHNA synthetic pathway was enhanced by overexpression of the endogenous MenFDHBCE gene cluster, resulting in $157 \mu \mathrm{M}$ of MK-7. Membrane engineering was further employed to increase MK-7, which led to $200 \mu \mathrm{M}(129 \mathrm{mg} / \mathrm{L}) \mathrm{MK}-7$ in a shake flask experiment. The authors conducted a fed-batch fermentation in a minimal medium using glucose as a substrate and achieved the highest titer of MK-7 ever reported up to $1.35 \mathrm{~g} / \mathrm{L}$ [100]. The engineered E. coli outperformed Bacillus and LAB by producing $1.35 \mathrm{~g} / \mathrm{L}$ of MK-7 during $52 \mathrm{~h}$ fermentation with increased titer and productivity when compared to other strains [100]. This result suggested that the microbial cell factory platform can be engineered and used for overproducing vitamin $\mathrm{K}$.

Liu et al. (2017) took a different approach to improve menaquinone synthesis by the engineering of the state of cell membrane in E. coli [101]. The authors investigated the role of the cell membrane. To verify whether the state of cell membrane can enhance MK synthesis, they constructed two engineered strains, E. coli DH5 $\alpha$ FatB and DH5 $\alpha$ FatA, which harbored FatB type acyl-ACP thioesterase from Umbellularia californica and the FatA type thioesterase from Sunflower, respectively. Since non-ionic surfactant-POE and plant oil-cedar wood oil (CWO) are known to increase extracellular secretion and intracellular synthesis of MK, the effects of these two chemicals on cell morphology and MK production of E. coli were investigated. As a result, E. coli $\mathrm{DH} 5 \alpha$ FatB exhibited strong MK secretion ability, resulting in $10.71 \pm 0.19 \mathrm{mg} / \mathrm{L}$ of extracellular MK [101].

Menaquinone-producing non-model microorganism, F. meningosepticum, was also engineered to enhance the menaquinone production by random mutagenesis. Tani et al. (2018) used NTG and HNA to construct F. meningosepticum mutants overproducing menaquinone [102]. Using glycerol as a substrate, the resulting mutant strain F. meningosepticum HNA 350-22 produced $23 \mathrm{mg} / \mathrm{L}$ of menaquinone, while the wild-type F. meningosepticum IFO 12535 strain produced $14.1 \mathrm{mg} / \mathrm{L}$ of menaquinone [102].

\section{Conclusions}

- Many studies for production of vitamin K using microorganisms have been conducted. Bacillus spp. are the most intensively studied microorganisms for vitamin K production. Many wild-type strains of Bacillus producing vitamin $\mathrm{K}$ have been isolated from soybean fermented foods, such as Natto and Cheonggukjang. Additionally, various LAB strains naturally producing different forms of vitamin $\mathrm{K}$ have been isolated and utilized for the manufacturing of vitamin K-enriched dairy products. Other than Bacillus and $\mathrm{LAB}$, few microorganisms have been studied and characterized for vitamin $\mathrm{K}$ production. Most of them were isolated from gut microbiota, which contributes to vitamin K production in the human body. Several microorganisms producing vitamin $\mathrm{K}$ are not GRAS microorganisms, which limits the registration and commercialization of fermented products. To utilize the microbial-derived vitamin $\mathrm{K}$ as a food supplement, microbial production hosts are required to be safe and registered as GRAS microorganisms. The GRAS wild-type microorganisms are safe to use, but typically exhibit low yields of vitamin $\mathrm{K}$. To improve the vitamin K production by the wild-type microorganisms, optimization of fermentation conditions and medium composition were mainly employed. Additionally, various chemical and physical methods, such 
as surfactant and ultrasound, have been used for increasing the biosynthesis and secretion of fat-soluble vitamin $\mathrm{K}$ out of the microbial cells.

- $\quad$ Random mutagenesis of the wild-type microorganisms can be used to increase vitamin $\mathrm{K}$ production, and vitamin $\mathrm{K}$ derived from the mutant strain is okay to use as a food ingredient. However, random mutagenesis strategy requires much time and effort to screen and select the mutants, which increased vitamin K production when compared to rational engineering. High-throughput screening methods may be utilized to accelerate the selection of vitamin K-overproducing strains from the mutant library.

- Microbial vitamin K production has also been improved by rational strain engineering strategies. These include overexpression of rate-limiting enzymes, deletion of competitive pathways, and fine-tuning of gene expression by modular system and quorum-sensing system. Although Bacillus, LAB, and other microbial cell factory platform strains have been engineered for overproduction of vitamin $\mathrm{K}$, the current titers are still not high enough to support the commercialization of microbial-derived vitamin $\mathrm{K}$ by fermentation. The titer, yield, and productivity of vitamin $\mathrm{K}$ by microorganisms should be further improved by advanced genetic and fermentation technologies [117]. Systems metabolic engineering, which integrates various engineering tools of systems biology, synthetic biology, and evolutionary engineering, can facilitate the development of vitamin K-hyperproducing strains [118]. Moreover, in silico metabolic modeling and machine learning may help to develop the vitamin K-producing microbial hosts as industrially competitive [119].

- A recent trend suggests that most consumers prefer to take "natural" products than "synthetic" products. The microbial derived-vitamin $\mathrm{K}$ as a natural food supplement can satisfy the market demand and sustainable development goals. Even if the engineered host strains are considered as genetically modified organisms (GMO), recent advances in genome editing tools such as CRISPR/Cas9 system allow us to construct marker-free recombinant strains, facilitating safe and sustainable production of food ingredients [120].

Author Contributions: Conceptualization, M.-J.K. and S.-O.S.; investigation, M.-J.K., K.-R.B., Y.-R.L., G.-H.K. and S.-O.S.; writing-original draft preparation, M.-J.K., K.-R.B., Y.-R.L., G.-H.K. and S.-O.S.; writing-review and editing, Y.-R.L. and S.-O.S. All authors have read and agreed to the published version of the manuscript.

Funding: This work was supported by the Catholic University of Korea, Research Fund, 2020.

Institutional Review Board Statement: Not applicable.

Informed Consent Statement: Not applicable.

Data Availability Statement: Not applicable.

Conflicts of Interest: The authors declare no conflict of interest.

\section{References}

1. Shah, K.; Gleason, L.; Villareal, D.T. Vitamin K and bone health in older adults. J. Nutr. Gerontol. Geriatr. 2014, 33, 10-22. [CrossRef]

2. Kamao, M.; Suhara, Y.; Tsugawa, N.; Uwano, M.; Yamaguchi, N.; Uenishi, K.; Ishida, H.; Sasaki, S.; Okano, T. Vitamin K content of foods and dietary vitamin K intake in Japanese young women. J. Nutr. Sci. Vitaminol. 2007, 53, 464-470. [CrossRef]

3. Basset, G.J.; Latimer, S.; Fatihi, A.; Soubeyrand, E.; Block, A. Phylloquinone (vitamin K1): Occurrence, biosynthesis and functions. Mini Rev. Med. Chem. 2017, 17, 1028-1038. [CrossRef]

4. Bentley, R.; Meganathan, R. Biosynthesis of vitamin K (menaquinone) in bacteria. Microbiol. Rev. 1982, 46, 241-280. [CrossRef]

5. Fusaro, M.; Mereu, M.C.; Aghi, A.; Iervasi, G.; Gallieni, M.J.; Metabolism, B. Vitamin K and bone. Clin. Cases Miner Bone Metab. 2017, 14, 200. [CrossRef]

6. Schurgers, L.; Geleijnse, J.; Grobbee, D.; Pols, H.; Hofman, A.; Witteman, J.; Vermeer, C. Nutritional intake of vitamins K1 (phylloquinone) and K2 (menaquinone) in the Netherlands. J. Nutr. Environ. Med. 1999, 9, 115-122. [CrossRef]

7. Van Oostende, C.; Widhalm, J.R.; Furt, F.; Ducluzeau, A.-L.; Basset, G.J. Vitamin K1 (phylloquinone): Function, enzymes and genes. Adv. Bot. Res. 2011, 59, 229-261. 
8. Mahdinia, E.; Demirci, A.; Berenjian, A. Production and application of menaquinone-7 (vitamin K2): A new perspective. World J. Microbiol. Biotechnol. 2017, 33, 2. [CrossRef]

9. Beulens, J.W.; Booth, S.L.; van den Heuvel, E.G.; Stoecklin, E.; Baka, A.; Vermeer, C. The role of menaquinones (vitamin K2) in human health. Br. J. Nutr. 2013, 110, 1357-1368. [CrossRef]

10. Vermeer, C.V. Vitamin K: The effect on health beyond coagulation-An overview. Food Nutr. Res. 2012, 56, 5329. [CrossRef]

11. Bus, K.; Szterk, A. Relationship between Structure and Biological Activity of Various Vitamin K Forms. Foods 2021, $10,3136$. [CrossRef]

12. DiNicolantonio, J.J.; Bhutani, J.; O'Keefe, J.H. The health benefits of vitamin K. Open Heart 2015, 2, e000300. [CrossRef]

13. Dam, H.; Schønheyder, F.; Tage-Hansen, E. Studies on the mode of action of vitamin K. Biochem. J. 1936, 30, 1075-1079. [CrossRef]

14. Olson, R.E.; Suttie, J.W. Vitamin K and gamma-carboxyglutamate biosynthesis. Vitam Horm. 1977, 35, 59-108. [CrossRef]

15. Akiyama, Y.; Hara, K.; Matsumoto, A.; Takahashi, S.; Tajima, T. Comparison of intestinal absorption of vitamin K2 (menaquinone) homologues and their effects on blood coagulation in rats with hypoprothrombinaemia. Biochem. Pharmacol. 1995, 49, 1801-1807. [CrossRef]

16. Halder, M.; Petsophonsakul, P.; Akbulut, A.C.; Pavlic, A.; Bohan, F.; Anderson, E.; Maresz, K.; Kramann, R.; Schurgers, L. Vitamin K: Double Bonds beyond Coagulation Insights into Differences between Vitamin K1 and K2 in Health and Disease. Int. J. Mol. Sci. 2019, 20, 896. [CrossRef]

17. Weber, P. Vitamin K and bone health. Nutrition 2001, 17, 880-887. [CrossRef]

18. Cockayne, S.; Adamson, J.; Lanham-New, S.; Shearer, M.J.; Gilbody, S.; Torgerson, D.J. Vitamin K and the prevention of fractures: Systematic review and meta-analysis of randomized controlled trials. Arch. Intern. Med. 2006, 166, 1256-1261. [CrossRef]

19. Simes, D.C.; Viegas, C.S.B.; Araújo, N.; Marreiros, C. Vitamin K as a Powerful Micronutrient in Aging and Age-Related Diseases: Pros and Cons from Clinical Studies. Int. J. Mol. Sci. 2019, 20, 4150. [CrossRef]

20. Iwamoto, J. Vitamin K2 Therapy for Postmenopausal Osteoporosis. Nutrients 2014, 6, 1971-1980. [CrossRef]

21. Knapen, M.H.J.; Drummen, N.E.; Smit, E.; Vermeer, C.; Theuwissen, E. Three-year low-dose menaquinone-7 supplementation helps decrease bone loss in healthy postmenopausal women. Osteoporos. Int. 2013, 24, 2499-2507. [CrossRef]

22. Shioi, A.; Morioka, T.; Shoji, T.; Emoto, M. The Inhibitory Roles of Vitamin K in Progression of Vascular Calcification. Nutrients 2020, 12, 583. [CrossRef] [PubMed]

23. Lees, J.S.; Chapman, F.A.; Witham, M.D.; Jardine, A.G.; Mark, P.B. Vitamin K status, supplementation and vascular disease: A systematic review and meta-analysis. Heart 2019, 105, 938-945. [CrossRef]

24. Zwakenberg, S.R.; de Jong, P.A.; Bartstra, J.W.; van Asperen, R.; Westerink, J.; de Valk, H.; Slart, R.; Luurtsema, G.; Wolterink, J.M.; de Borst, G.J.; et al. The effect of menaquinone-7 supplementation on vascular calcification in patients with diabetes: A randomized, double-blind, placebo-controlled trial. Am. J. Clin. Nutr. 2019, 110, 883-890. [CrossRef]

25. Ingles, D.P.; Cruz Rodriguez, J.B.; Garcia, H. Supplemental Vitamins and Minerals for Cardiovascular Disease Prevention and Treatment. Curr. Cardiol. Rep. 2020, 22, 22. [CrossRef]

26. Ferland, G. Vitamin K, an emerging nutrient in brain function. Biofactors 2012, 38, 151-157. [CrossRef]

27. Vervoort, L.M.; Ronden, J.E.; Thijssen, H.H. The potent antioxidant activity of the vitamin K cycle in microsomal lipid peroxidation. Biochem. Pharmacol. 1997, 54, 871-876. [CrossRef]

28. Li, J.; Lin, J.C.; Wang, H.; Peterson, J.W.; Furie, B.C.; Furie, B.; Booth, S.L.; Volpe, J.J.; Rosenberg, P.A. Novel role of vitamin k in preventing oxidative injury to developing oligodendrocytes and neurons. J. Neurosci. Off. J. Soc. Neurosci. 2003, 23, 5816-5826. [CrossRef]

29. Li, J.; Wang, H.; Rosenberg, P.A. Vitamin K prevents oxidative cell death by inhibiting activation of 12-lipoxygenase in developing oligodendrocytes. J. Neurosci. Res. 2009, 87, 1997-2005. [CrossRef]

30. Ren, L.; Peng, C.; Hu, X.; Han, Y.; Huang, H. Microbial production of vitamin K2: Current status and future prospects. Biotechnol. Adv. 2020, 39, 107453. [CrossRef]

31. Krajewski, K.; Kutner, A.; Dzikowska, J.; Gutowska, R.; Napiórkowski, M.; Winiarski, J.; Kubiszewski, M.; Jedynak, Ł.; Morzycki, J.; Witkowski, S. Process for Preparation of MK-7 Type of Vitamin K2. Google Patents US9828323B2, 28 November 2017.

32. Skattebol, L.; Aukrust, I.R.; Sandberg, M. Process for the Preparation of Vitamin K2. Google Patents EP2346806A1, 6 January 2016.

33. Xu, Y.; Zhang, L.; Yang, R.; Yu, X.; Yu, L.; Ma, F.; Li, H.; Wang, X.; Li, P. Extraction and Determination of Vitamin K1 in Foods by Ultrasound-Assisted Extraction, SPE, and LC-MS/MS. Molecules 2020, 25, 839. [CrossRef] [PubMed]

34. Tarento, T.D.C.; McClure, D.D.; Talbot, A.M.; Regtop, H.L.; Biffin, J.R.; Valtchev, P.; Dehghani, F.; Kavanagh, J.M. A potential biotechnological process for the sustainable production of vitamin K1. Crit. Rev. Biotechnol. 2019, 39, 1-19. [CrossRef] [PubMed]

35. Du, J.; Shao, Z.; Zhao, H. Engineering microbial factories for synthesis of value-added products. J. Ind. Microbiol. Biotechnol. 2011, 38, 873-890. [CrossRef] [PubMed]

36. Johnson, E.T.; Schmidt-Dannert, C. Light-energy conversion in engineered microorganisms. Trends Biotechnol. 2008, 26, 682-689. [CrossRef]

37. Lal, N.; Berenjian, A. Cis and trans isomers of the vitamin menaquinone-7: Which one is biologically significant? Appl. Microbiol. Biotechnol. 2020, 104, 2765-2776. [CrossRef]

38. Szterk, A.; Zmysłowski, A.; Bus, K. Identification of cis/trans isomers of menaquinone-7 in food as exemplified by dietary supplements. Food Chem. 2018, 243, 403-409. [CrossRef] 
39. Wang, Y.; Liu, L.; Jin, Z.; Zhang, D. Microbial Cell Factories for Green Production of Vitamins. Front. Bioeng. Biotechnol. 2021, 9, 661562. [CrossRef]

40. Aguiar, T.Q.; Silva, R.; Domingues, L. Ashbya gossypii beyond industrial riboflavin production: A historical perspective and emerging biotechnological applications. Biotechnol. Adv. 2015, 33, 1774-1786. [CrossRef]

41. Abbas, C.A.; Sibirny, A.A. Genetic control of biosynthesis and transport of riboflavin and flavin nucleotides and construction of robust biotechnological producers. Microbiol. Mol. Biol. Rev. 2011, 75, 321-360. [CrossRef]

42. Nielsen, J. Metabolic engineering. Appl. Microbiol. Biotechnol. 2001, 55, 263-283. [CrossRef]

43. Zhang, Y.; Zhu, Y.; Zhu, Y.; Li, Y. The importance of engineering physiological functionality into microbes. Trends Biotechnol. 2009, 27, 664-672. [CrossRef] [PubMed]

44. Biedendieck, R.; Malten, M.; Barg, H.; Bunk, B.; Martens, J.-H.; Deery, E.; Leech, H.; Warren, M.J.; Jahn, D. Metabolic engineering of cobalamin (vitamin B12) production in Bacillus megaterium. Microb. Biotechnol. 2010, 3, 24-37. [CrossRef] [PubMed]

45. LeBlanc, J.; Laiño, J.E.; del Valle, M.J.; Vannini, V.; van Sinderen, D.; Taranto, M.P.; de Valdez, G.F.; de Giori, G.S.; Sesma, F. B-Group vitamin production by lactic acid bacteria-current knowledge and potential applications. J. Appl. Microbiol. 2011, 111, 1297-1309. [CrossRef] [PubMed]

46. Fang, H.; Li, D.; Kang, J.; Jiang, P.; Sun, J.; Zhang, D. Metabolic engineering of Escherichia coli for de novo biosynthesis of vitamin B12. Nat. Commun. 2018, 9, 4917. [CrossRef]

47. Zhang, Z.; Liu, L.; Liu, C.; Sun, Y.; Zhang, D. New aspects of microbial vitamin K2 production by expanding the product spectrum. Microb. Cell Fact. 2021, 20, 84. [CrossRef]

48. Westers, L.; Westers, H.; Quax, W.J.J.B.e.B.A.-M.C.R. Bacillus subtilis as cell factory for pharmaceutical proteins: A biotechnological approach to optimize the host organism. Biochim. Biophys. Acta (BBA)-Mol. Cell Res. 2004, 1694, 299-310. [CrossRef]

49. Berenjian, A.; Mahanama, R.; Talbot, A.; Biffin, R.; Regtop, H.; Valtchev, P.; Kavanagh, J.; Dehghani, F. Efficient media for high menaquinone-7 production: Response surface methodology approach. New Biotechnol. 2011, 28, 665-672. [CrossRef]

50. Berenjian, A.; Mahanama, R.; Talbot, A.; Biffin, R.; Regtop, H.; Kavanagh, J.; Dehghani, F. The effect of amino-acids and glycerol addition on MK-7 production. Proc. World Congr. Eng. Comput. Sci. 2011, 11, 19-21.

51. Berenjian, A.; Mahanama, R.; Talbot, A.; Regtop, H.; Kavanagh, J.; Dehghani, F. Advances in menaquinone-7 production by Bacillus subtilis natto: Fed-batch glycerol addition. Am. J. Biochem. Biotechnol. 2012, 8, 105-110.

52. Berenjian, A.; Mahanama, R.; Talbot, A.; Regtop, H.; Kavanagh, J.; Dehghani, F. Designing of an intensification process for biosynthesis and recovery of menaquinone-7. Appl. Biochem. Biotechnol. 2014, 172, 1347-1357. [CrossRef]

53. Hu, X.-C.; Liu, W.-M.; Luo, M.-M.; Ren, L.-J.; Ji, X.-J.; Huang, H. Enhancing Menaquinone-7 Production by Bacillus natto R127 Through the Nutritional Factors and Surfactant. Appl. Biochem. Biotechnol. 2017, 182, 1630-1641. [CrossRef] [PubMed]

54. Mahdinia, E.; Demirci, A.; Berenjian, A. Strain and plastic composite support (PCS) selection for vitamin K (Menaquinone-7) production in biofilm reactors. Bioprocess Biosyst. Eng. 2017, 40, 1507-1517. [CrossRef] [PubMed]

55. Mahdinia, E.; Demirci, A.; Berenjian, A. Enhanced Vitamin K (Menaquinone-7) Production by Bacillus subtilis natto in Biofilm Reactors by Optimization of Glucose-based Medium. Curr. Pharm. Biotechnol. 2018, 19, 917-924. [CrossRef] [PubMed]

56. Mahdinia, E.; Demirci, A.; Berenjian, A. Utilization of glucose-based medium and optimization of Bacillus subtilis natto growth parameters for vitamin K (menaquinone-7) production in biofilm reactors. Biocatal. Agric. Biotechnol. 2018, 13, 219-224. [CrossRef]

57. Mahdinia, E.; Demirci, A.; Berenjian, A. Implementation of fed-batch strategies for vitamin K (menaquinone-7) production by Bacillus subtilis natto in biofilm reactors. Appl. Microbiol. Biotechnol. 2018, 102, 9147-9157. [CrossRef]

58. Mahdinia, E.; Demirci, A.; Berenjian, A. Optimization of Bacillus subtilis natto growth parameters in glycerol-based medium for vitamin K (Menaquinone-7) production in biofilm reactors. Bioprocess Biosyst. Eng. 2018, 41, 195-204. [CrossRef]

59. Mahdinia, E.; Demirci, A.; Berenjian, A. Effects of medium components in a glycerol-based medium on vitamin K (menaquinone-7) production by Bacillus subtilis natto in biofilm reactors. Bioprocess Biosyst. Eng. 2019, 42, 223-232. [CrossRef]

60. Mahdinia, E.; Demirci, A.; Berenjian, A. Evaluation of vitamin K (menaquinone-7) stability and secretion in glucose and glycerol-based media by Bacillus subtilis natto. Acta Aliment. 2019, 48, 405-414. [CrossRef]

61. Novin, D.; van der Wel, J.; Seifan, M.; Berenjian, A. The effect of aeration and mixing in developing a dairy-based functional food rich in menaquinone-7. Bioprocess Biosyst. Eng. 2020, 43, 1773-1780. [CrossRef]

62. Singh, R.; Puri, A.; Panda, B.P.P. Development of menaquinone-7 enriched nutraceutical: Inside into medium engineering and process modeling. J. Food Sci. Technol. 2015, 52, 5212-5219. [CrossRef]

63. Ranmadugala, D.; Ebrahiminezhad, A.; Manley-Harris, M.; Ghasemi, Y.; Berenjian, A. Impact of 3-AminopropyltriethoxysilaneCoated Iron Oxide Nanoparticles on Menaquinone-7 Production Using B. subtilis. Nanomaterials 2017, 7, 350. [CrossRef] [PubMed]

64. Wu, W.-J.; Ahn, B. Improved menaquinone (Vitamin K 2) production in cheonggukjang by optimization of the fermentation conditions. Food Sci. Biotechnol. 2011, 20, 1585-1591. [CrossRef]

65. Zhao, C.; Wan, Y.; Tang, G.; Jin, Q.; Zhang, H.; Xu, Z. Comparison of different fermentation processes for the vitamin K2 (Menaquinone-7) production by a novel Bacillus velezensis ND strain. Process Biochem. 2021, 102, 33-41. [CrossRef]

66. Morishita, T.; Tamura, N.; Makino, T.; Kudo, S. Production of menaquinones by lactic acid bacteria. J. Dairy Sci. 1999, 82, 1897-1903. [CrossRef]

67. Lim, S.-D.; Kim, K.-S.; Do, J.-R. Physiological characteristics and production of vitamin K 2 by Lactobacillus fermentum LC272 isolated from raw milk. Food Sci. Anim. Resour. 2011, 31, 513-520. [CrossRef] 
68. Liu, Y.; van Bennekom, E.O.; Zhang, Y.; Abee, T.; Smid, E.J. Long-chain vitamin K2 production in Lactococcus lactis is influenced by temperature, carbon source, aeration and mode of energy metabolism. Microb. Cell Fact. 2019, 18, 129. [CrossRef]

69. Wei, H.; Wang, L.; Zhao, G.; Fang, Z.; Wu, H.; Wang, P.; Zheng, Z. Extraction, purification and identification of menaquinones from Flavobacterium meningosepticum fermentation medium. Process Biochem. 2018, 66, 245-253. [CrossRef]

70. Fang, X.; Yang, Q.; Liu, H.; Wang, P.; Wang, L.; Zheng, Z.; Zhao, G. Effects of a combined processing technology involving ultrasound and surfactant on the metabolic synthesis of vitamin K2 by Flavobacterium sp. M1-14. Chem. Eng. Processing-Process Intensif. 2019, 135, 227-235. [CrossRef]

71. Cooke, G.; Behan, J.; Costello, M. Newly identified vitamin K-producing bacteria isolated from the neonatal faecal flora. Microb. Ecol. Health Dis. 2006, 18, 133-138.

72. Mahdinia, E.; Demirci, A.; Berenjian, A. Biofilm reactors as a promising method for vitamin K (menaquinone-7) production. Appl. Microbiol. Biotechnol. 2019, 103, 5583-5592. [CrossRef]

73. Mahdinia, E.; Mamouri, S.J.; Puri, V.M.; Demirci, A.; Berenjian, A. Modeling of vitamin K (Menaquinoe-7) fermentation by Bacillus subtilis natto in biofilm reactors. Biocatal. Agric. Biotechnol. 2019, 17, 196-202. [CrossRef]

74. Walther, B.; Karl, J.P.; Booth, S.L.; Boyaval, P. Menaquinones, Bacteria, and the Food Supply: The Relevance of Dairy and Fermented Food Products to Vitamin K Requirements. Adv. Nutr. 2013, 4, 463-473. [CrossRef] [PubMed]

75. Chollet, M.; Guggisberg, D.; Portmann, R.; Risse, M.-C.; Walther, B. Determination of menaquinone production by Lactococcus spp. and propionibacteria in cheese. Int. Dairy J. 2017, 75, 1-9. [CrossRef]

76. Hojo, K.; Watanabe, R.; Mori, T.; Taketomo, N. Quantitative measurement of tetrahydromenaquinone-9 in cheese fermented by propionibacteria. J. Dairy Sci. 2007, 90, 4078-4083. [CrossRef] [PubMed]

77. LeBlanc, J.G.; Milani, C.; de Giori, G.S.; Sesma, F.; van Sinderen, D.; Ventura, M. Bacteria as vitamin suppliers to their host: A gut microbiota perspective. Curr. Opin. Biotechnol. 2013, 24, 160-168. [CrossRef]

78. Ceyhan, M.; Celik, M. Elizabethkingia meningosepticum (Chryseobacterium meningosepticum) infections in children. Int. J. Pediatrics 2011, 2011, 215237. [CrossRef] [PubMed]

79. Reddy, R.M.; Reddy, P.G.; Seenayya, G. Enhanced production of thermostable $\beta$-amylase and pullulanase in the presence of surfactants by Clostridium thermosulfurogenes SV2. Process Biochem. 1999, 34, 87-92. [CrossRef]

80. Ellis, J.L.; Karl, J.P.; Oliverio, A.M.; Fu, X.; Soares, J.W.; Wolfe, B.E.; Hernandez, C.J.; Mason, J.B.; Booth, S.L. Dietary vitamin K is remodeled by gut microbiota and influences community composition. Gut Microbes 2021, 13, 1887721. [CrossRef]

81. Fernandez, F.; Collins, M.D. Vitamin K composition of anaerobic gut bacteria. FEMS Microbiol. Lett. 1987, 41, 175-180. [CrossRef]

82. Yu, Q.; Li, Y.; Wu, B.; Hu, W.; He, M.; Hu, G. Novel mutagenesis and screening technologies for food microorganisms: Advances and prospects. Appl. Microbiol. Biotechnol. 2020, 104, 1517-1531. [CrossRef] [PubMed]

83. Sato, T.; Yamada, Y.; Ohtani, Y.; Mitsui, N.; Murasawa, H.; Araki, S. Production of Menaquinone (vitamin K2)-7 by Bacillus subtilis. J. Biosci. Bioeng. 2001, 91, 16-20. [CrossRef]

84. Song, J.; Liu, H.; Wang, L.; Dai, J.; Liu, Y.; Liu, H.; Zhao, G.; Wang, P.; Zheng, Z. Enhanced Production of Vitamin K2 from Bacillus subtilis (natto) by Mutation and Optimization of the Fermentation Medium. Braz. Arch. Biol. Technol. 2014, 57, 606-612.

85. Tsukamoto, Y.; Kasai, M.; Kakuda, H. Construction of a Bacillus subtilis (natto) with high productivity of vitamin K2 (menaquinone-7) by analog resistance. Biosci. Biotechnol. Biochem. 2001, 65, 2007-2015. [CrossRef]

86. Wang, H.; Sun, X.; Wang, L.; Wu, H.; Zhao, G.; Liu, H.; Wang, P.; Zheng, Z. Coproduction of menaquinone-7 and nattokinase by Bacillus subtilis using soybean curd residue as a renewable substrate combined with a dissolved oxygen control strategy. Ann. Microbiol. 2018, 68, 655-665. [CrossRef]

87. Puri, A.; Iqubal, M.; Zafar, R.; Panda, B.P. Influence of physical, chemical and inducer treatments on menaquinone-7 biosynthesis by Bacillus subtilis MTCC 2756. Songklanakarin J. Sci. Technol. 2015, 37, 283-289.

88. Goodman, S.R.; Marrs, B.L.; Narconis, R.J.; Olson, R.E. Isolation and description of a menaquinone mutant from Bacillus licheniformis. J. Bacteriol. 1976, 125, 282-289. [CrossRef]

89. Xu, J.-Z.; Zhang, W. Menaquinone-7 production from maize meal hydrolysate by Bacillus isolates with diphenylamine and analogue resistance. J. Zhejiang Univ. Sci. B 2017, 18, 462-473. [CrossRef]

90. Liu, N.; Ruan, H.; Liu, L.; Zhang, W.; Xu, J. Temperature-induced mutagenesis-based adaptive evolution of Bacillus amyloliquefaciens for improving the production efficiency of menaquinone-7 from starch. J. Chem. Technol. Biotechnol. 2021, 96, 1040-1048. [CrossRef]

91. Xu, J.-Z.; Yan, W.-L.; Zhang, W.-G. Enhancing menaquinone-7 production in recombinant Bacillus amyloliquefaciens by metabolic pathway engineering. RSC Adv. 2017, 7, 28527-28534. [CrossRef]

92. Ma, Y.; McClure, D.D.; Somerville, M.V.; Proschogo, N.W.; Dehghani, F.; Kavanagh, J.M.; Coleman, N.V. Metabolic Engineering of the MEP Pathway in Bacillus subtilis for Increased Biosynthesis of Menaquinone-7. ACS Synth. Biol. 2019, 8, 1620-1630. [CrossRef]

93. Yang, S.; Cao, Y.; Sun, L.; Li, C.; Lin, X.; Cai, Z.; Zhang, G.; Song, H. Modular pathway engineering of Bacillus subtilis to promote de novo biosynthesis of menaquinone-7. ACS Synth. Biol. 2018, 8, 70-81. [CrossRef]

94. Yuan, P.; Cui, S.; Liu, Y.; Li, J.; Lv, X.; Liu, L.; Du, G. Combinatorial engineering for improved menaquinone-4 biosynthesis in Bacillus subtilis. Enzym. Microb. Technol. 2020, 141, 109652. [CrossRef] 
95. Cui, S.; Lv, X.; Wu, Y.; Li, J.; Du, G.; Ledesma-Amaro, R.; Liu, L. Engineering a bifunctional Phr60-Rap60-Spo0A quorum-sensing molecular switch for dynamic fine-tuning of menaquinone-7 synthesis in Bacillus subtilis. ACS Synth. Biol. 2019, 8, $1826-1837$. [CrossRef]

96. Yuan, P.; Sun, G.; Cui, S.; Wu, Y.; Lv, X.; Liu, Y.; Li, J.; Du, G.; Liu, L. Engineering a ComA Quorum-Sensing circuit to dynamically control the production of Menaquinone-4 in Bacillus subtilis. Enzym. Microb. Technol. 2021, 147, 109782. [CrossRef]

97. Cui, S.; Xia, H.; Chen, T.; Gu, Y.; Lv, X.; Liu, Y.; Li, J.; Du, G.; Liu, L. Cell membrane and electron transfer engineering for improved synthesis of menaquinone-7 in Bacillus subtilis. iScience 2020, 23, 100918. [CrossRef]

98. Bøe, C.A.; Holo, H. Engineering Lactococcus lactis for Increased Vitamin K2 Production. Front. Bioeng. Biotechnol. $2020,8,191$. [CrossRef]

99. Kong, M.K.; Lee, P.C. Metabolic engineering of menaquinone-8 pathway of Escherichia coli as a microbial platform for vitamin K production. Biotechnol. Bioeng. 2011, 108, 1997-2002. [CrossRef]

100. Gao, Q.; Chen, H.; Wang, G.; Yang, W.; Zhong, X.; Liu, J.; Huo, X.; Liu, W.; Huang, J.; Tao, Y.; et al. Highly Efficient Production of Menaquinone-7 from Glucose by Metabolically Engineered Escherichia coli. ACS Synth. Biol. 2021, 10, 756-765. [CrossRef]

101. Liu, Y.; Ding, X.-M.; Xue, Z.-L.; Hu, L.-X.; Zhang, N.-J.; Wang, Z.; Yang, J.-W.; Cheng, Q.; Chen, M.-H.; Zhang, Z.-Z.; et al. The change of the state of cell membrane can enhance the synthesis of menaquinone in Escherichia coli. World J. Microbiol. Biotechnol. 2017, 33, 52. [CrossRef]

102. Tani, Y.; Asahi, S.; Yamada, H. Menaquinone (vitamin K2)-6 production by mutants of Flavobacterium meningosepticum. J. Nutr. Sci. Vitaminol. 1986, 32, 137-145. [CrossRef]

103. Moon, G.-S.; Pyun, Y.-R.; Park, M.S.; Ji, G.E.; Kim, W.J. Secretion of recombinant pediocin PA-1 by Bifidobacterium longum, using the signal sequence for bifidobacterial $\alpha$-amylase. Appl. Environ. Microbiol. 2005, 71, 5630-5632. [CrossRef] [PubMed]

104. Park, M.; Seo, J.; Kim, J.; Ji, G. Heterologous gene expression and secretion in Bifidobacterium longum. Le Lait 2005, 85, 1-8. [CrossRef]

105. Oh, J.-H.; van Pijkeren, J.-P. CRISPR-Cas9-assisted recombineering in Lactobacillus reuteri. Nucleic Acids Res. 2014, 42 , e131. [CrossRef] [PubMed]

106. Stout, E.A.; Sanozky-Dawes, R.; Goh, Y.J.; Crawley, A.B.; Klaenhammer, T.R.; Barrangou, R. Deletion-based escape of CRISPR-Cas9 targeting in Lactobacillus gasseri. Microbiology 2018, 164, 1098-1111. [CrossRef] [PubMed]

107. Jang, Y.-J.; Seo, S.-O.; Kim, S.-A.; Li, L.; Kim, T.-J.; Kim, S.C.; Jin, Y.-S.; Han, N.S. Elimination of the cryptic plasmid in Leuconostoc citreum by CRISPR/Cas9 system. J. Biotechnol. 2017, 251, 151-155. [CrossRef] [PubMed]

108. Briner, A.E.; Lugli, G.A.; Milani, C.; Duranti, S.; Turroni, F.; Gueimonde, M.; Margolles, A.; Van Sinderen, D.; Ventura, M.; Barrangou, R. Occurrence and diversity of CRISPR-Cas systems in the genus Bifidobacterium. PLoS ONE 2015, 10, e0133661. [CrossRef]

109. Liu, L.; Yang, D.; Zhang, Z.; Liu, T.; Hu, G.; He, M.; Zhao, S.; Peng, N. High-Efficiency Genome Editing Based on Endogenous CRISPR-Cas System Enhances Cell Growth and Lactic Acid Production in Pediococcus acidilactici. Appl. Environ. Microbiol. 2021, 87, e0094821. [CrossRef]

110. Yang, D.; Park, S.Y.; Park, Y.S.; Eun, H.; Lee, S.Y. Metabolic engineering of Escherichia coli for natural product biosynthesis. Trends Biotechnol. 2020, 38, 745-765. [CrossRef]

111. Chen, X.; Zhou, L.; Tian, K.; Kumar, A.; Singh, S.; Prior, B.A.; Wang, Z. Metabolic engineering of Escherichia coli: A sustainable industrial platform for bio-based chemical production. Biotechnol. Adv. 2013, 31, 1200-1223. [CrossRef]

112. Lee, S.Y.; Kim, H.U. Systems strategies for developing industrial microbial strains. Nat. Biotechnol. 2015, 33, 1061-1072. [CrossRef]

113. Meganathan, R. Biosynthesis of the isoprenoid quinones menaquinone (vitamin K_2) and ubiquinone (coenzyme Q). In Escherichia Coli and Salmonella: Cellular and Molecular Biology; ASM Press: Washington, DC, USA, 1996; pp. 642-656.

114. Lin, E.; Kuritzkes, D. Pathways for anaerobic electron transport. In Escherichia Coli and Salmonella Typhimurium: Cellular and Molecular Biology; American Society for Microbiology: Washington, DC, USA, 1987; pp. 201-221.

115. Olson, R.E.; Rudney, H. Biosynthesis of ubiquinone. Vitam. Horm. 1983, 40, 1-43. [PubMed]

116. Meganathan, R.; Kwon, O. Biosynthesis of Menaquinone (Vitamin K2) and Ubiquinone (Coenzyme Q). EcoSal Plus $2009,3$. [CrossRef] [PubMed]

117. Seo, S.O.; Jin, Y.S. Next-Generation Genetic and Fermentation Technologies for Safe and Sustainable Production of Food Ingredients: Colors and Flavorings. Annu. Rev. Food Sci. Technol. 2022, 13. [CrossRef] [PubMed]

118. Choi, K.R.; Jang, W.D.; Yang, D.; Cho, J.S.; Park, D.; Lee, S.Y. Systems Metabolic Engineering Strategies: Integrating Systems and Synthetic Biology with Metabolic Engineering. Trends Biotechnol. 2019, 37, 817-837. [CrossRef]

119. Presnell, K.V.; Alper, H.S. Systems Metabolic Engineering Meets Machine Learning: A New Era for Data-Driven Metabolic Engineering. Biotechnol. J. 2019, 14, 1800416. [CrossRef]

120. Hidalgo-Cantabrana, C.; O'Flaherty, S.; Barrangou, R. CRISPR-based engineering of next-generation lactic acid bacteria. Curr. Opin. Microbiol. 2017, 37, 79-87. [CrossRef] 